\title{
INVESTMENT DRIVING FORCES AFECTING LITHUANIAN ECONOMIC GROWTH
}

\author{
Manuela Tvaronaviciene \\ Vilnius Gediminas Technical University, Saulètekio al. 11, LT-10223 Vilnius, Lithuania \\ E-mail:manuela@vv.vtu.lt
}

Received 0601 2006; accepted 27022006

\begin{abstract}
Presented publication presents a complex research model embracing a series of investigations related to assessment of driving forces affecting economic growth processes in Lithuania. New approach towards impact of foreign direct investment (FDI) on economic development of transition country is emphasized. Speculations on FDI efficiency follow elaboration of factors initiating FDI. FDI and foreign trade are seen as specific factors affecting restructuring of transition country as it follows consistent patterns of development. Policy implications are formulated.
\end{abstract}

Keywords: FDI, foreign trade, economic restructuring, economic development.

\section{Development of theoretical model of the research}

Research objective is to trace main forces affecting growth of Lithuanian economy, i.e. to ground theoretically hypotheses concerning concrete factors affecting economic growth of transition country, set limitations of research. Direction of impact of chosen for investigation factors and quantitative evaluation of this impact, in cases when it is feasible, is the compound part of an objective being targeted. Economic policy implications are seen as rationale of results obtained results.

In order to implement formulated objective a set of following research questions are to be tackled. In Figure 1 relevance of the research questions to the research objective (relevance tree) or research model is grounded.

Impact of foreign direct investments (FDI) on economic growth of transition country is to be considered. Detailed theoretical argumentation and practical evidences on economies' development accelerating and retarding phenomena are to be presented. The aim is to prevent plausible growth hindering effects by irrelevant FDI stimulation policy.

Driving factors moving FDI into other countries are to be elaborated. Legal business environment as manageable one is been focused on. Especial attention to such politically sensitive questions as tax system as tax burden has been paid. Presented research question is if tax concessions are of high importance among other investment driving forces for capital exporting country.

Bankruptcy of firms is to be analyzed in the context of foreign newcomer's pressure and in context of micro and macro factors affecting its activity and bankruptcy. We strive to clarify what factors dominate in conditioning local business failure: local or outer, particularly, foreign capital ones.

Mode of FDI accumulation is seen as significant determinant of foreign capital inflows stimulation and, factor conditioning FDI efficiency from the host country point of view. In this context privatization policies' analysis, appropriate case studies and detailed Lithuanian stock exchange functioning analysis is to be performed. This research question is to be elaborated having aim to detect if FDI attract by privatization policy is efficient in terms of economic growth of host country.

FDI serves as an important factor of economic restructuring. Impact of separately taken foreign capital flows on expanding or shrinking of main Lithuanian economic sectors is to be examined and quantitatively estimated; implications of FDI con- 
ditioned structural changes on economic growth elaborated. Implication of research question is forecasting of restructuring directions conditioned by different level of saturation by FDI by main Lithuanian economic sectors.

As economic restructuring itself is seen as a topical issue determining pace of economic growth of transition country, this research question has been emphasized. Efficient economic structure is in research is to be targeted. For that purpose, benchmarking attempts are discussed, benchmarking limitations indicated and, finally, empirical evidences of Lithuania and other transition countries considered. Aim is to trace how much Lithuanian development correspond benchmark and coincide with development routs of other transition countries. Admitting existence of consistent patterns in development rout and taking into account limitations of the benchmarking, assumption about foreign trade as factor affecting deviations from benchmarked economic structure is to be elaborated.

Interrelationship of foreign trade with FDI and economic restructuring is to be theoretically grounded and statistically tested. Rationale lies in elaboration of state policy implications in field of FDI, foreign trade and economic restructuring in order to enhance economic growth of Lithuanian economy.

\section{Role of distinguished factors affecting Lithuanian economic growth}

Foreign direct investments have been tackled as one of the most important driving forces influencing economic development of a country in transition path. FDI analysis led to identify that cumulative inflows of foreign capital positively and rather significantly affect economic development of Lithuania and its Baltic neighbors [1, 2]. Nevertheless, close look at driving factors and sources of FDI led to assumption that separate inflows of foreign capital rather differently impact economic development of a transition country. Quantitative analysis verified theoretical speculations about plausible negative consequences of certain FDI inflows [3, 4].

The corollary about negative impact of certain FDI inflows on economic development has led to state policy considerations. Juxtapose of legal business environment, particularly in field of different tax systems, on the one hand, and FDI inflows, on the other, in Baltic countries let to assert that tax systems do not play such significant role as they are supposed to in conditioning efficient investment stimuli [5-9]. Extended further Lithuanian tax burden analysis led to intuition that tax burden but not tax concession is serves as more significant investment factor in this context [10].

Business environment studies were continued by scrutinizing bankruptcy phenomenon in Lithuania. On the one hand, impact of legislative basis (what is legal environment, in fact) and micro-factors on bankruptcy scale were analyzed [11, 12], and, on the other hand, impact macroeconomic factors on the same dependent variable have been quantitatively assessed [13]. The results verified that business environment could be characterized by a set of indicators and taxes are not prevailing in conditioning general business climate. To conclude, the main aspect of policy implications is that there is no need to overemphasize role of tax system in the process of FDI attracting aiming to stimulate economic growth. Another important, to author's mind, result is that foreign capital firms stimulate bankruptcies of local ones.

Returning to FDI analysis it is important to stop on sources of foreign capital inflows. Mode of FDI accumulation is seen as being intertwined with driving factors' rubric. Privatization phenomenon in this case serves as a vivid example of FDI sources and driving factors being overlapped. Analysis of FDI tendencies and efficiency in Lithuania revealed that foreign capital inflows attracted by privatization were not always efficient from the host country point of view [14]. The conclusion was, that privatization policy plays crucial role in predetermining future efficiency of privatized enterprise [15-16]. Inefficiency of FDI, when enterprise is to be sold to so called "strategic investor" is more plausible compared to case when inflows of foreign capital is to be channeled through stock exchange [17-18].

FDI impacts economic growth mainly through capital accumulation and technology spillovers. Main sectors of economics are characterized by different level of FDI saturation. Mode of foreign capital inflow, susceptibility to spillovers and capital enhancement, all together, condition restructuring of host country economy. Research results indicate that the highest level of FDI saturation is characteristic for trade, financial intermediation and industrial sectors. Nevertheless, only sector of financial intermediation due to FDI impact will expand significantly $[9,19]$.

Introducing changing economic structure as conse- 


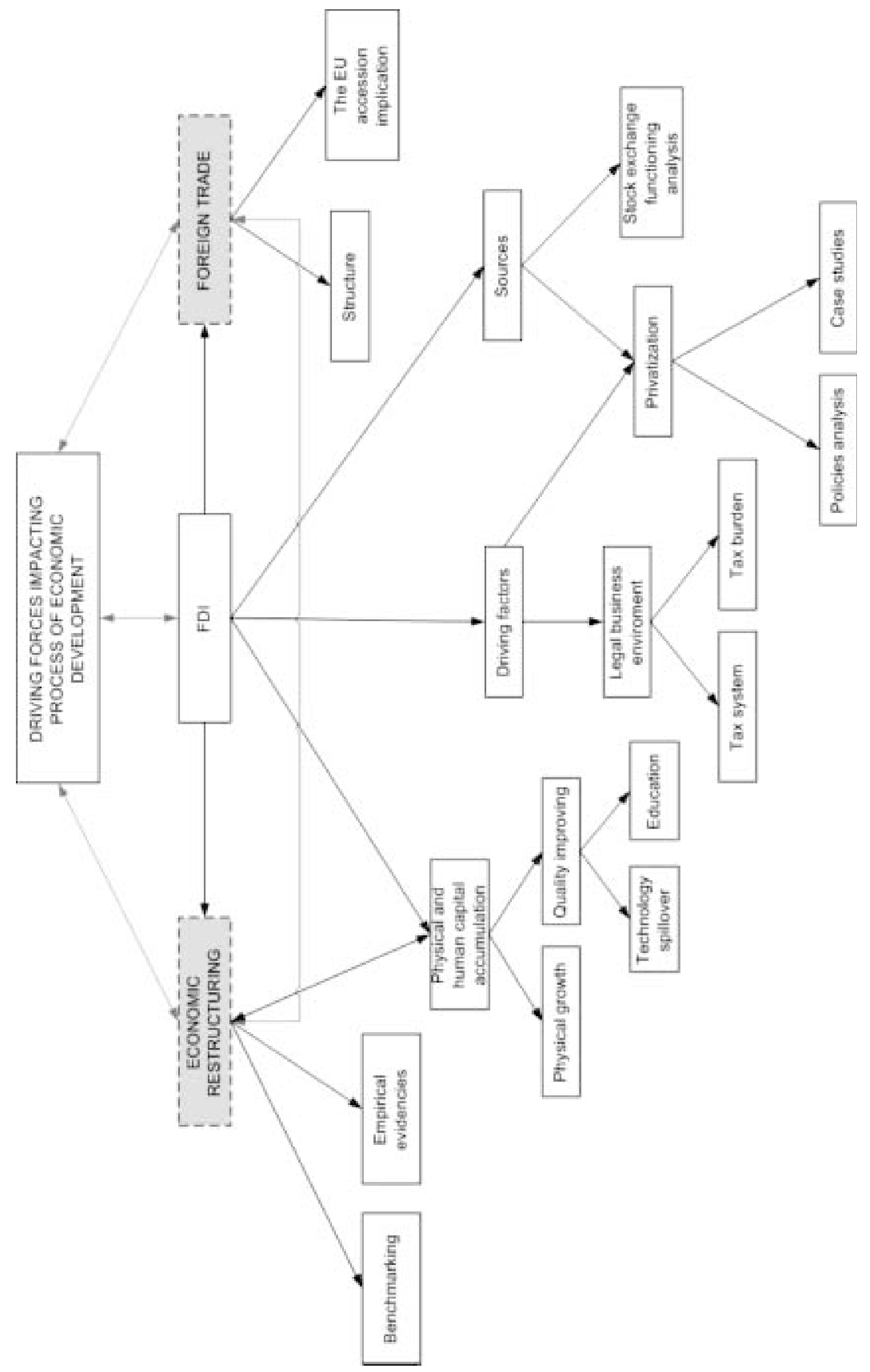

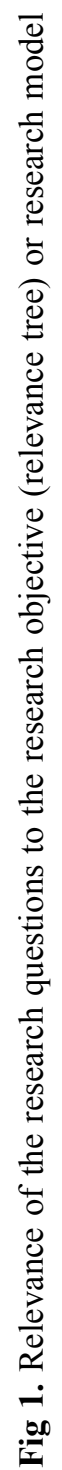


quence of FDI impact raises questions related to efficient restructuring of transition economy. In this context benchmarking and deviations from benchmarked structure is elaborated. Research results confirm that transition countries follow a certain consistent patterns of development: agricultural and industry share is reducing, while services are expanding [20]. Changing conditions distort follow up consistent pattern of development as ceteris paribus is not met. The EU accession has changed pattern of export causing development of unskilled labor production [21-22]. State policy directed to hindering of observed export tendencies is to be adopted [21].

\section{Course of elaboration of main corrolaries}

Recall that FDI serves as central axis of elaborated model (Fig 1). Legal business environment is seen one of the most important stimuli attracting foreign capital inflows. Tax system by majority of authors is treated as the most urgent and tangable part of leagal business environment. In our investigation, we question efficiency of tax concesions and using cases of Baltic States try to reveal if young transition countries with especially favorable investment conditions grow more rapidly than countries applying more modest investment stimuli.

Such premise might seem controversial for developed countries, but situation, in which young independent states found themselves after segregation from Soviet Union, was different: all of them were at the very beginning of process of creating market relationships, enterprises of state capital dominated, private capital was in the stage of formation and operated in relatively uncompetitive environment. Such situation, at the one hand, stipulated intensive processes of privatization, and, on the other hand, offered for other developed countries chance of entering new markets actually free of strong rivals. Natural process of expanding activity into not occupied yet markets stipulated FDI. Another characteristic feature of entrance of foreign capital was that, at first, it flew into monopolistic spheres of economy. Favorable conditions for occupation of monopolistic positions were fostered by governments, which, drastically needed money and offered incredible favorable conditions of privatization (as the most characteristic example privatization of Lithuanian Telecom could be referred - the most profitable enterprise in Baltic countries was privatized with condition to guarantee monopolistic conditions until 2003 year). Process of privatization, sometimes with signs of corruption, stipulated that growth of FDI has not induced appropriate growth of GDP. This tendency was especially obvious in Lithuania, where role of privatization in attracting FDI was the greatest and level of corruption the highest. Hence, we can conclude that role of tax incentives in young transition countries case is diminished by other factors, and strongly investment oriented tax policies on the early stage of development of market can lead to diminishing of budget revenues from profit tax.

Performed comparison of tax systems in Baltic States Lithuania, Latvia and Estonia yields following tax policy implications: tax system, conditioning especially favorable investment conditions in young transition economies does not play the role, which was predetermined to it. Therefore, there is no point in introducing special tax incentives in forms of tax concessions on capital invested. According economic rationale, strong relationship between profit received by enterprise and volume of capital invested exists. Hence, the main emphasis should be put on creation for favorable conditions of business firms operation without distinction of origin of capital invested. Firms, witch balance on the edge of profit and losses do not gain from tax concessions on capital invested at all, while profitable firms have possibilities escape taxes through inflating capital costs.

So instead tax concessions on capital invested, young transition countries should concentrate on attracting "green field" investments by guaranteeing stability of once implemented business conditions, continuity of already started reforms and, what is not of less importance, reducing bureaucratic hurdles and increasing transparency of decisions of civil servants.

In Lithuania, labor is taxed much heavier than capital: personal income tax is $33 \%$ and profit tax is $15 \%$. It means that economic sectors using comparatively higher share of labor are taxed more than capitalintensive industries. Transition period is characterized by changing economic structure, as it has to adapt to market needs. Changing economic structure means that some economic sectors are expanding and others are shrinking. That, ceteris paribus, causes change of labor and capital intensity used in GDP generation, and, consequently, changes tax burden. Developed countries, as a rule, have more even taxation of labor and capital, and more stable economic structure. Hence, impact of structural changes on tax burden is more plausible in transition countries. 
Authors performed analysis of impact of economic structure change on tax burden indicator during 19932000 years. Various levels of aggregation and different sets of economic activities have been tested. Authors chose a model including six main economic activities industry, wholesale and retail trade, transport, real estate, agriculture and construction. Indicated activities comprise $70 \%$ of GDP, determination coefficient equals 0.95 .

The corollary is that expanding industry and agriculture, both diminish tax burden, and expanding services (trade and transport in our model) tend to increase tax burden [10].

Returning to the driving forces of FDI and relationship between tax environment (tax concessions and tax burden particularly) let us compare tax burden in countries investors and Lithuania. Countries could be attributed to tree categories - having tax burden above $40 \%$, having tax burden within 30-40\%, and, below $30 \%$. Recall, that Lithuanian main investors are Sweden, Denmark, Finland and USA. The northern countries fall into the first category with tax burden nearing to $50 \%$. USA falls into the third category together with such countries as Mexico, Japan and Lithuania. That notice is commensurate with our conclusions about inefficiency of tax concessions as FDI stimulator. Difference in tax burdens, as in case of Scandinavian investors, or access to new emerging markets, as supposed to be in case of USA, are seen as the most important investment stimuli. Expanding services and shrinking industry and agriculture (typical tendencies of restructuring as it will be shown below) would gradually increase tax burden and diminish FDI stimuli. To put into other way, as country develops FDI driving forces weakens.

Review of economical literature leads to conclusions that affect of FDI on development of economy of host country could be different and, even, quite controversial. In one case globalization can initiate growth of GDP through increase in quality and quantity of goods produced and services provided. It conditions spillover of knowledge, technologies experience to local companies, what enable them to survive even in environment of increased competition. In another case, globalization in sectors with high barriers of entry can enjoy favorable business conditions, extract rent and replace local economical entities out of market.

Performed economical analysis revealed that in Lithuania globalization of service sector positively impact economical growth, while globalization of industry sector do not [1].

Investigation has led to corollary that positive and negative impact of globalization is concurrent. Some inflows of foreign capital into the same sector of economy can be efficient from the point of view of host country, and some not. In transition countries, negative result of globalization most probably could be traced in privatized monopolies.

In Lithuanian economy, the highest level of globalization has been determined in trade, financial intermediation and industry. In some cases, replacement of local firms took place, what confirms theoretical premises about malign impact of globalization.

Globalization process effects restructuring of national economy. Considering results of performed analysis we can expect that in the future sector of financial intermediation will expand significantly.

Quantitative evaluation of FDI efficiency is rather complicated task and requires setting a series of presumptions. Authors have raised the following questions: the first, if growth of FDI is commensurate with growth of FDI; the second, if growth of FDI causes bankruptcies of local firms, and the third one is if different inflows of foreign capital have different impact on growth of national economy. After stop on the first two quantitative relationships, we scrutinized the third one. Hence, simple correlation analysis verified availability of significant positive relationship between FDI and GDP growth. On the other hand, calculations confirmed assumption about failures of local firms due to pressure of foreign capital (increase in FDI is commensurate with increase in bankruptcy numbers [13]).

Quantitative evaluation of impact of separate foreign capital inflows on growth of national economy is rather new approach to speculations about FDI efficiency. It is considered as important one, as results would let to reveal certain cases and circumstances in which globalization represents threat to growth of national economy, and therefore should be prevented rather than stimulated by local government. Strength and direction of relationship between FDI structure and GDP would present direct answer to the question about efficiency of FDI directed to the different sectors of economy. Agriculture, industry and services as the most important economic sectors were targeted. 
At the first stage of economic interpretation of calculation results let us to concentrate on relationship between FDI into main sectors of Lithuanian economy and GDP. Correlation coefficient between FDI share to agriculture and GDP is negative and insignificant. Hence, conclusion is that FDI to agriculture in Lithuanian case do not affect properly growth of GDP.

In the further analysis we put emphasis on FDI into services and industry. Interrelationships between FDI into those sectors and GDP are strong and significant: correlation coefficient between FDI share into services and FDI is equal to 0.99 , and between FDI to industry and GDP correspondingly equals to -0.81 [1].

Hence, application of mathematical method confirmed theoretical premise about controversial impact of globalization of separate sectors on economical growth. In our case, we received negative relationship between FDI share directed to industry and GDP, what indicated that globalization of industry sector retards development of economy. Hence, application of mathematical method confirmed theoretical premise about controversial impact of globalization of separate sectors on economical growth.

Generalizing Lithuanian case should be stated that the highest level of globalization has been determined in financial intermediation, trade and industry. Despite the analysis indicated that in Lithuania globalization of service sector positively affect economical growth, separate capital inflows into some activities comprising service sector retard economic growth. The most positive effect has foreign investments into financial intermediation, and the most negative effect have been traced in sphere of communication. Globalization of industry sector does not have positive impact on development of economy of host country. The latter result is rather alerting as mainly industrial sector conditions export. Closer look to export structure and tendencies led to the following interpretation of obtained results: Lithuanian industry enhances export to the EU at a cost of increase of lowskilled intensive products - the tendency, which could not be assessed positively [23]).

Analysis of neighboring countries Estonia and Latvia confirmed premise about quite controversial role of FDI in transition economies development. Another point of interest is that almost the same economic sectors were saturated by FDI, what lets treat Baltic States as one economic area despite differences, which could be distinguished.

\section{Conclusions}

Tax concessions as important part of legal business environment do not perform efficient role in attracting inflows of foreign capital. Differences in tax burdens and access to new emerging markets are supposed to be more important investment stimuli. Privatisation process played the most important role as driving factor and source of FDI.

FDI controversially affects growth of an economy by physical capital accumulation, technology, know-how spillovers at some sectors, and by using advantages of high entry barriers and causing bankruptcies of local firms. Restructuring of economy is commensurate of FDI, the corollary we came to in our research. Another important question is how much the restructuring caused by FDI corresponds consistent patterns of development if such exist.

Efficient structure of economy or targeted ratio between industry, services and agriculture, estimated in employment terms, remain rather obscure. Nevertheless, theoretical speculations and quantitative analysis lead to corollary that certain consistent patterns of structural changes, as country develops in GDP per capita terms, exist. Author have come to the idea, that transition countries at the current moment of development decrease their industrial sector, develop services and contract agricultural employment.

Comparisons of structural transition path and current economy structure of CEE countries has let to distinguish some peculiarities of development. We see productivity of various sectors of economy, geographical allocation and composition of exports as the most important driving forces conditioning deviations of particular countries from benchmarked economic structure.

Considering listed theoretical findings, we suggest the following economic policy implications for Lithuania. The first, the sector of agriculture has to be actively contracted, at least in employment terms - corollary grounded theoretically and verified by correlation analysis performed on Lithuanian statistical data. The second, as exports (due to new export regime related the EU accession) will be more oriented towards the $\mathrm{EU}$, industry has to be reoriented towards production of skilled-labor and capital-intensive goods. Intuition is that relying on growing low-skilled-products exports should not be economically encouraged as retards spillover of labor force to service sector, and in that way delay efficient transforming of Lithuanian economic structure in conformity with consistent pattern of development. 


\section{References}

[1] Tvaronavičienè, M.; Kalašinskaitè K. Tiesioginis užsienio investicijų efektyvumo įvertinimas Baltijos šalyse. Verslas: teorija ir praktika (Business: Theory and Practice). Vilniaus Gedimino technikos universiteto mokslo žurnalas/ Vilniaus Gedimino technikos universitetas. ISSN 1648-0627. 2003, T. IV, Nr. 3, p. 129-141.

[2] Ginevičius, R.; Tvaronavičienè, M. Globalization processes in Baltic countries: analysis of trends in Lithuania, Latvia and Estonia. Journal of Business Economics and Management / North-German Academy of Informatology (Stralsund). ISSN 1611-1699, 2003, Vol IV, No 1, p. 62-71.

[3] Ginevicius, R.; Tvaronaviciene, M. What drives foreign direct investments into Baltic Countries? The case of Lithuania, Latvia and Estonia). Ekonomicky Casopis (Journal of Economics) / Institute of Slovak and World Economy SAS. ISSN 0013-3035. 2003, Vol 51, No 8, p. $963-981$.

[4] Ginevicius, R.; Tvaronaviciene, M. Risk of globalization: case study of Lithuanian economy. Ekonomicky Casopis (Journal of Economics) / Institute of Slovak and World Economy SAS. ISSN 0013-3035. 2004, Vol 52, No 2, p. 212-231.

[5] Ginevicius, R.; Tvaronaviciene, M. Comparative analysis of tax systems in Lithuania, Latvia and Estonia. In: Studies in Industrial Engineering and Management. No 16. Ten yers of economic transformation. Societies and institutions in transition. Lappeenranta University of Technology. ISSN 1455-0415. 2001, Vol III, No 16, p. $127-45$.

[6] Ginevicius, R.; Tvaronaviciene, M. Legal business environment and investment stimuli in Lithuania. In: Almanach des praktischen Managements in Mittel- und Ost-Europa: Ausgewählte Artikel Schwerpunkt Estland/ Lettland/ Litauen. Stralsund: Nordic Academy of Informatization. ISSN 1439-0833. 2001, Band 3, p. 25-28.

[7] Ginevicius, R.; Tvaronaviciene, M. Foreign direct investments: perception of external business environment and performance. The case study of Lithuania, Latvia and Estonia. In: Nowe pogranicze Europy: Litwa, Lotwa, Estonia. Praca zbiorowa pod redakcija Eufemia Teichmann. Szkola Glowna Handlowa, Kolegium Gospodarki Swiatowej. ISBN 83-208-1457-x, Warszawa, 2003, p. 89105.

[8] Tvaronaviciene, M. Inflow of foreign capital: whether different approaches to tax reform matter - evidence from the Baltic states (1995-2000). EBS Review: Finance, Accounting and Economics/ Estonian
Business School. Tallinn: 2002. Summer 2002, No 14, p. 40-48.

[9] Ginevicius, R.; Tvaronaviciene, M. Tax evasion trough offshore companies: How important the phenomenon is? Journal of Business Economics and Management / North-German Academy of Informotology (Stralsund). ISSN 1611-1699. 2004, Vol V, No 1, p. 25-31.

[10] Meškauskienè, D.; Tvaronavičienè, M. Lietuvos mokesčių sistema: mokesčių naštos tyrimas. Verslas: teorija ir praktika (Business: Theory and Practice): Vilniaus Gedimino technikos universiteto mokslo zurnalas/Vilniaus Gedimino technikos universitetas. ISSN 1648-0627. 2003, T. IV, Nr. 1, p. 36-42.

[11] Tvaronavičienè, M. Approaches to process enterprise bankprutcy in Lithuania. In: Almanach des praktischen Managements in Mittel- und Ost-Europa: Ausgewählte Artikel Schwerpunkt Estland/ Lettland/ Litauen. Stralsund: Nordic Academy of Informatization. ISSN 1439-0833. 2001, Band 3, p. 102-106.

[12] Tvaronavičienė, M. Imonių bankroto proceso ekonominio efektyvumo didinimo kryptys. Ekonomika: mokslo darbai / Vilniaus universitetas. Vilnius: VU l-kla, ISSN 1392-1258. 2001, T. 54, p. 135-144.

[13] Juchno, N.; Tvaronavičienè, M. Imoniu bankrotai Lietuvoje: priklausomybės nuo makroekonominiu veiksnių tyrimas. Verslas: teorija ir praktika (Business: Theory and Practice). Vilniaus Gedimino technikos universiteto mokslo žurnalas / Vilniaus Gedimino technikos universitetas. ISSN 1648-0627. 2004, T. V, Nr. 2, p. 65-72.

[14] Tvaronavičienè, M.; Kalašinskaite, K. Tiesioginès užsienio investicijos ị Lietuvos ūkị: tendencijų ir efektyvumo ivertinimas. Verslas: teorija ir praktika (Business: Theory and Practice). Vilniaus Gedimino technikos universiteto mokslo žurnalas/ Vilniaus Gedimino technikos universitetas. ISSN 1648-0627. 2003, T. IV, Nr. 2, p. 61-71.

[15] Tvaronavičienè, M.; Kalašinskaitè, K. Analysis of privatization: Different approaches. Journal of Business Economics and Management / North-German Academy of Informotology (Stralsund). ISSN 1611-1699. 2005, Vol VI, No 1, p. 53-59.

[16] Tvaronavičienè, M.; Ananeva, V. Lietuvos Telekomo privatizavimo bei funkcionavimo ypatybès Europos Sajungos šalių kontekste. Verslas: teorija ir praktika (Business: Theory and Practice). Vilniaus Gedimino technikos universiteto mokslo žurnalas / Vilniaus Gedimino technikos universitetas. ISSN 1648-0627. 2004, T. V, Nr. 4, p. 167-175.

[17] Ginevicius, R.; Tvaronaviciene, M. Stock exchanges of Baltic countries: development and procpectives. Journal of Business Economics and Management / 
North-German Academy of Informatology (Stralsund). ISSN 1611-1699. 2003, Vol IV, No 2, p. 130-143.

[18] Tvaronavičienė, M.; Rafael, Ž. Vertybinių popieriu rinka Lietuvoje: aktyvumo įvertinimas bei pagrindiniu veiksnių analizè. Verslas: teorija ir praktika (Business: Theory and Practice. Vilniaus Gedimino technikos universiteto mokslo žurnalas / Vilniaus Gedimino technikos universitetas. ISSN 1648-0627. 2004, T. IV, Nr. 1, p. 10-21.

[19] Tvaronaviciene, M. Foreign direct investments and efficiency of structural changes in local economy: Case of Lithuania. In: $8^{\text {th }}$ International Conference on Global Business and Economic Development: Managing a Volatile Environment: Balancing Local and Global Chalanges. January 7-10, 2004, Guadalajara, Mexico, $\mathrm{CD}$ of proceedings.

[20] Tvaronavičienè, M. Theoretical framework for restructuring of transition countries. Journal of Business Economics and Management/ North-German Academy of Informatology (Stralsund). ISSN 16111699. 2004, Vol V, No 2, p. 103-108.

[21] Ginevicius, R.; Tvaronaviciene, M. Lithuania on the eve of European Union Accession. In: A wider Europe and the new neighborhood policy of the European Union: Selected aspects of Poland's and the Baltic States' relations with Russia and Belarus. Edited by Eufemia Teichmann, The Baltic States Study Center, World Economy Research Institute. Warsaw School of Economics, World Economy Faculty, ISBN 83-7378117-X, Warszaw, 2004, p. 211-215.

[22] Ginevicius, R.; Tvaronaviciene, M. Enlarged European Union and its Eastern Neighbours. Initial experiences of co-operation. In: Rozszerzona Unia Europejska i Jej Wschodni Sasiedzi. Pierwsze Doswiadczenia Wspolpracy. Redakcja naukowa E.Teichmann, M.A. Weresa. Szkola Glowna Handlowa w Warszawe. Warszawa, 2005, p. 183-195.

[23] Tvaronaviciene, M. Implications of EU accession on foreign trade of Lithuania. In: International Scientific Conference: UNITECH'04 Gabrovo. Proceedings Volume III. ISBN 954-683-305-3. November 18-19, Gabrovo: University Publishing House "V. Aprilov", 2004, p. 168-173. 